\title{
Sumbangan Pemikiran Muhammad Yamin dalam Sejarah Indonesia
}

\author{
Nirwan Yasin ${ }^{1}$, Lagut Bakaruddin ${ }^{2}$ \\ ${ }^{1,2}$ Fakultas Ilmu Budaya, Universitas Jambi, Muaro Jambi, 36122, Indonesia \\ *email:lagutbakaruddin@gmail.com
}

\begin{abstract}
Abstrak
Tujuan dari penulisan artikel ini adalah untuk menelaah dan membahas sumbangan pemikiran tokoh nasional Muhammad Yamin dalam sejarah Indonesia pada masa awal kemerdekaan Indonesia. Muhammad Yamin banyak menaruh perhatiannya dalam bidang sejarah Indonesia pada masa awal kemerdekaan. Pada masa awal pembentukan negara Indonesia, sejarah Indonesia masih didominasi oleh aliran Nederland sentris atau Eropa sentris. Maka di sini muncullah sebuah ide dari tokoh-tokoh bangsa untuk mengoreksi ulang penulisan sejarah Indonesia ke aliran sejarah Indonesia sentris. Muahammad Yamin adalah salah satu tokohnya. Muhammad Yamin dengan karyanya tentang konsepsi sejarah romantik yang mengungkapkan masa lalu. Di samping itu, melalui syair-syair perjuangan Muhammad Yamin mengungkapkan sejarah nasional Indonesia sebagai bentuk nasionalisme.
\end{abstract}

Kata Kunci: Muhammad Yamin, sejarah Indonesia

\begin{abstract}
The purpose of writing this article is to examine and discuss the contribution of the thought of national figure Muhammad Yamin in Indonesian history in the early days of Indonesian independence. Muhammad Yamin paid much attention to the field of Indonesian history in the early days of independence. During the initial formation of the Indonesian state, Indonesia's history was still dominated by centristed or European centricism. So here an idea emerged from the nation's figures to re-correct the writing of Indonesian history to the centric flow of Indonesian history. Muhammad Yamin is one of the characters. Muhammad Yamin with his work on the conception of romantic history that reveals the past. Muhammad Yamin with his work on the conception of romantic history that reveals the past. In addition, through the poems of Muhammad Yamin's struggle revealed the national history of Indonesia as a form of nationalism. Keywords: Muhammad Yamin, Indonesian history
\end{abstract}

\section{Pendahuluan}

Apabila tercapainya suatu kemerdekaan serta terbentuknya sebuah negara nasioal maka timbullah keperluan untuk menulis sejarah Indonesia sebagai sejarah nasional. Cakrawala relio-magis serta kosmogonis seperti yang tercantum dalam babad atau hikayat telah ditinggalkan diganti dengan cakrawala empiris-ilmiah, cakrawala natiosentris yang mengantikan ethnocentrisme, cakrawala kolonial-elits yang diganti dengan sejarah bangsa yang mencakup keseluruhanya (Kartodirdjo, 2017). 
Bangsa Indonesia yang baru merdeka 17 agustus 1945, setelah kemerdekaan maka bangsa Indonesia sebagai bangsa wajib mempertanggung jawabkan sejarah masa silamnya. Dengan ini bukan berarti bangsa Indonesia harus membolak balikkan fakta sejarah. Sejarah sebagai kisah haruslah berdasarkan fakta yang benar, dengan demikian barulah sejarah Indonesia dapat dimengerti (Kartodirdjo, 2017).

Dengan demikian kesadaran sejarah nasional dalam mendorong lahirnya pemikiran sejarah nasional di Indonesia mengambil jalan yang berbeda dengan apa yang terjadi di Eropa. Jika di Eropa tuntutan nasionalismenya dan pemikiran sejarah nasionalnya hadir terhadap kekuasaan rezim lama dan dampak dari revolusi Perancis, maka di Indonesia nasionaisme lahir sebagai reaksi masyarakat terhadap penjajahan Belanda (Zed, 2010).

Pada awal kemerdekaan muncullah beberapa tokoh yang memberikan perhatianya terhadap sejarah bangsa sebagai bentuk nasionalisme. Salah satunya adalah Muhammad Yamin (1903-1962) kelahiran Talawi, Sawahlunto, Sumatera Barat, termasuk tokoh nasional maha putera Republik Indonesia yang banyak mencurahkan perhatiannya terhadap sejarah tanah air. Meski bidangnya di Ilmu Hukum, Yamin menaruh perhatian yang sangat luas dalam bidang sejarah. Pendiriannya bahwa untuk penulisan sejarah Indonesia atau sejarah nasional mutlak diperlukan filsafat sejarah nasional (Zed, 2010). Berdasarkan hal tersebut, maka penulisan ini bermaksud untuk melihat lebih lanjut konsep dan sumbangan pemikiran Muhammad Yamin dalam filsafat sejarah Indonesia.

\section{Metode Penelitian}

Pendekatan yang digunakan adalah penelitian metode kualitatif. Pendekatan kualitatif adalah suatu proses pengambilan data-data tertulis dari kejadiaan atau fonomena (Hizkia, 2016). Untuk menjelaskan penelitiaan ini maka digunakan metode deskriptif. Metode deskriptif dapat diartikan sebagai prosedur atau cara memecahkan masalah penelitian dengan memaparkan keadaan objek yang diselidiki berdasarkan fakta yang aktual (Hadari \& Martini, 1992).

Adapun teknik pengumpulan data melalui kajian pustaka dengan mengumpulkan data yang dilakukan denga mempergunakan bahan-bahan tertulis sebagai dokumen seperti buku, koran, majalah, jurnal, skripsi, jurnal, tesis, desertasi dan lain sebagainya (Hadari \& Martini, 1992). Pengumpulan data dilakukan pada Perpustakaan Universitas Jambi, Perpustkaan Daerah Provinsi Jambi, Perpusatkaan FIB UNJA, FKIP UNJA, FAH UIN Jambi, buku online, jurnal online dan koleksi buku pribadi yang berkaitan dengan tema.

\section{Pembahasan}

\section{Penulisan Sejarah Indonesia Awal Kemerdekaan}

Dasar dari negara Republik Indonesia merupakan wilayah bekas jajahan Belanda yang berlangsug abad ke 17 M sampai $20 \mathrm{M}$. Namun demikian tidak semuanya wilayah di Indonesia diduduki selama itu oleh Belanda, misalnya Aceh hanya berlangsung selama 33 tahun (Ismail, 2017). Dilihat dari letak geografis, dari Sabang sampai Marauke, terbentang tidak sedikit pulau di Indonesia. Dengan pulau besar, mulai dari Sumatera, Jawa, Kalimantan, Bali, Nusa Tenaggara, Sulawesi, Kepulauan Maluku, hinga Papua, serta pulau kecil lainnya yang mengelilingi Indonesia (Sudirman, 2014). 
Semenjak Indonesia merdeka 1945, maka semenjak itu ada kegiatan mengubah penulisan sejarah Indonesia sentris. Artinya bangsa Indonesia memfokuskan perhatian, sasaran, dan ungkapan sesuai dengan kondisi bangsa Indonesia dimulai dari segala aspek yang meliputi politik, sosial, ekonomi, dan budaya. Selain itu, bangsa Indonesia juga berusaha untuk tidak mencenderungkan kepada penulisan sejarah Indonesia yang bersifat Nederland sentris (Nurhayati, 2016).

Pergerakan yang telah dilakukan oleh kaum nasional dalam melawan kolonial Belanda telah melahirkan rekontruksi sejarah yang secara historis mengatakan bahwa Indonesia dan Belanda merupakan bangsa yang sejajar. Mohammad Ali (1963) mengatakan pada dasarnya sejarah berfungsi membangkitkan jiwa perjuangan dan memperkokoh kehormatan pada diri sendiri sebagai rakyat dan sekaligus menghilangkan rasa rendah diri dihadapan Bangsa Belanda, demikian menunjukan adanya kesatuan Indonesia pada masa lampau. Kata Indonesia dijadikan label untuk menyatakan wilayah Indonesia pada masa lampau, khususnya eks Hindia Belanda (Purwanto, 2001).

Berdasarkan kenyataanya pada penulisan awal sejarah Indonesia, ada usaha menggabungkan Sriwijaya, Majapahit, Patimura, Diponegoro, dan Sumpah Palapa (Purwanto, 2001). Dengan demikian penulisan dan pemunculan sejarah Indonesia pada masa awal murni dilakukan untuk mebangkitkan rasa nasionalisme dan mebangkitkan rasa kebesaran bangsa Indonesia dalam menentang kolonial Belanda.

Penulisan sejarah Indonesia pada masa awal dalam konteks politik memunculkan tokoh-tokoh seperti Muhammad Yamin, Seokarno, Sanusi Pane, atau bahkan Sartono Kartodjirjo. Dalam hal ini, perjuangan politik Indonesia pada masa itu memang diakui memerlukan legimitasi untuk membangun nasionalisme sebagai ideologi. Anakronisme dalam penulisan sejarah Indonesia pada masa itu merupakan sesuatu hal yang tidak perlu diperdebatkan. Sementara itu anakronisme dalam penulisan sejarah Indonesia pada awal kemerdekaan tidak lain dari historiografi yang didasarkan pada kepentingan nasionalisme pada saat itu (Purwanto, 2001).

Muhammad Yamin seorang ahli hukum yang menaruh perhatiannya terhadap kelangsungngan sejarah Indonesia termasuk dari beberapa tokoh penulisan sejarah pada masa awal dengan pemikiran-pemikirannya dalam bidang sejarah dan seorang tokoh nasionalisme dengan berbagai pendekatan ilmu dalam mewujudkan nasionalisme pada awal kemerdekaan. Pada masa awal tujuan utama adalah merdeka, maka diperlukan nasionalisme untuk mewujudkan kemerdekaan. Nasionalisme dilakukan dengan berbagai cara termasuk dalam historiografi penulisan sejarah Indonesia.

\section{Pemikiran Muhammad Yamin terhadap Sejarah Indonesia}

\section{Profil Kehidupan Muhammad Yamin}

Muhammad Yamin dilahirkan di Sawahlunto Sumatera Barat pada tangal 23 Agustus 1903. Adapun pendidikan dasar di tempuh (VS dan HIS) dan menengah (NS, LVS, dan AMS) di laluinya di Padang, Bogor, dan Yokyakarta. Kemudian gelar sarjana hukum diperoleh di Jakarta pada tahun 1932. Semenak zaman pergerkaan nasional Muhammd Yamin aktif di berbagai organisasi seperti: Jong Sumatranen Bond (19161918), organisasi Indonesia Muda (1928), Partindo (1932-1938), dan Parpindo (19381942). Beliau memiliki talenta di bidang Sejarah dan Sastra (Suwirta, 2006).

Pada masa pemerintahan Jepang (1942-1945) Muhammad Yamin aktif dalam majelis pertimbangan PUTERA (Pusat Tenaga Rakyat), salah satu organisasi pada masa 
pemerintahan Jepang. Sebelum kemerdekaan Indonesia, Muhammad Yamin pernah menjadi angota BPUPKI dan PPKI yang ikut merumuskan dasar Negara Indonesia merdeka. Kemudian pasca Indonesia Merdeka Muhammad Yamin menjabat menjadi menteri PP dan K (Suwirta, 2006).

\section{Sumbangan Pemikiran Muhammad Yamin terhadap Sejarah Indonesia}

Penulisan sejarah nasional secara umum dapat dilihat sebagai anti tesis terhadap penulisan sejarah kolonial atau eropasentris yang dianggap tidak cocok sesuai dengan tuntutan zaman sebagai alternatifnya perlu pendekatan baru yang lebih sesuai dengan kondisi iklim Indonesia pasca kolonial. Kemudian muncul perdebatan masalah filsafat sejarah apa perlu tidaknya pengkajian filsafat sejarah dalam penulisan sejarah Indonesia. Muhammad Yamin salah satu pencetus menyatakan bahwa perlunya filsafat sejarah dalam menulis sejarah Indonesia (Zed, 2010).

Kiprah Muhamamd Yamin dalam Sejarah Indonesia yaitu karya buku yang berjudul Gadjah Mada, Pahlawan Persatuaan Nasional, dan 6000 Tahun Persatuaan Nasional. Dalam hal ini, Yamin telah memetakan bahwa persatuaan nasionalisme Indonesia sudah ada semenjak 6000 tahun yang lalu, kemudian dari pada Yamin berpendapat setidaknya sudah ada semenjak Sriwijaya dan Majapahit (Wood, 2013).

Gadjah Mada merupakan karya Muhammad Yamin pada tahun 1948. Gadjah Mada dipercaya sebagai orang yang menyatukan Nusantara atau Indonesia pada hari ini. Dalam buku ini, Yamin mengemukakan juga kegelimangngan Majapahit. Dalam buku yang berjul 6000 tahun merah putih. Dalam buku ini, Yamin berusaha menyelidiki tentang warna bendera merah putih dan buku ini diluncurkan perayaan sepuluh tahun perayaan sumpah pemuda karena berkaitan dengan simbol negara, maka kelahiran warna tersebut perlu diselidiki dalam kebudayaan indonesia (Jaelani, 2018).

Tulisan Muhamamd Yamin yang berkaitan dengan Filsafat Sejarah merujuk pada Ibnu Khaldun tentang kekuatan primodarial. Kemudian yang harus dirujuk dari pemikiran asli Indonesia adalah kitab Negarakertagama. Disinilah nasionalisme jati diri bangsa Indonesia dan tidak bisa terpengaruh dari yang lain. Namun sebaliknya gagaan yang ditemukan Yamin jika ditelusuri merupakan warisan dari kolonial yang menemukan naskah Negarakertagama dan mengajarkanya kepada pelajar Indonesia terkait sosok Muhamamd Yamin. Kemudian hari dikritik bahwa Muhamamd Yamin dalam penerimaannya secara mentah tanpa dimatangkan terlebih dahulu. Kemudian hal inilah yang selanjutnya berkembang dan di ajarkan di sekolah-sekolah (Bachtiar, 2018).

\section{Kesimpulan}

Muhammad Yamin sebagai tokoh nasionalis bangsa dan termasuk pejuang kemerdekaan. Kemudian di samping itu Muhammad Yamin juga berkontribusi dalam penulisan sejarah Indonesia. Seperti ada beberapa karya yang digagasnya, seperti Gadjah Mada, 6000 Tahun Merah Putih, dan Tentara Perjuangan. Adapun kritik terhadap gagasan Muhammad Yamin adalah Kitab Negarakertagama yang mana dalam penafsirannya masih bersifat kolonial sentris dan masih mengacu pada penulisan sejarah oleh kolonial. Sehingga kritikan itu muncul terhadap seajarah Majapahit pada hari ini yang diagung-agungkan dan Gadjah Mada ditampilkan sebagai pemersatu Nusantara. Pada dekade awal tidak dapat dipungkiri bahwa penulisan sejarah Indonesia lebih dipentingkan sebagai pemersatu bangsa dan menumbuhkan semangat 
nasionalisme bangsa pada awal kemerekaan. Namun dalam tahap selanjutnya penulisan sejarah versi Yamin perlu dikoreksi ulang oleh para generasi sejarah di bawahnya.

\section{Referensi}

Bachtiar, T.A. (2018). Islamisasi Penulisan Sejarah: Survey Gagasan Hamka, Syed Naquib Al-Attas, dan Ahmad Mansur Suryanegara. JUSPI (Jurnal Sejarah Peradaban Islam), 2(2), 1-16.

Jaelani, G.A. (2018). Nasionalisasi Pengetahuan Sejarah: Meninjau Kembali Agenda Penulisan Sejarah Indonesiasentris, 1945-1965. Jurnal Sejarah. Vol, 2(1), 1-29.

Hadari \& Martini. (1992). Instrumen Penelitian Sosial. Yogyakarta: UGM Press.

Ismail, F. (2017). Panorama Sejarah Islam dan Politik di Indonesia. Yogyakarta: Diva Press.

Kartodirdjo, S. (2017). Pemikiran dan Perkembangan Historiografi Indonesia. Yogyakarta: Ombak.

Nurhayati. (2016). Penulisan Sejarah (Historiografi): Mewujudkan Nilai-Nilai Kearifan Budaya Lokal Menuju Abad 21. Jurnal, FKIP Universitas Muhammadiyah Palembang, 1(1), 255-266.

Purwanto, B. (2001). Memahami Kembali Nasionalisme Indonesia. Jurnal Ilmu Sosial dan Ilmu Politik, 4(3), 243-264.

Suwirta, A. (2006). Visi Muhammad Yamin dan Sadarjoen Siswomartojo tentang Pentingnya Pendidikan Guru Tingkat Universitas di Indonesia. Journal of Historical Studies, 7, 2.

Sudirman, A. (2014). Sejarah Lengkap Indonesia. Yogyakarta: Diva Press.

Tobing, D.H., dkk. (2018) Bahan Ajar Metode Penelitian Kualitatif. Denpasaar. Program Studi Psikologi Kakultas Kedokteran UniversitasUdayana.https://simdos.unud.ac.id/uploads/file_pendidikan_1_dir 870ba33936829bb37ecd8f62f8514ba7.pdfh

Wood, M. (2013). Sejarah Resmi Indonesia versi Orde Baru dan Para Penentangnya. Yogyakarta: Ombak

Zed, M. (2020). Pengantar Filsafat Sejarah. Padang: UNP Press. 